\title{
Sources, cycling and export of nitrogen on the Greenland Ice Sheet
}

\author{
Jemma Louise Wadham ${ }^{1}$, Jonathan Hawkings ${ }^{1}$, Jon Telling ${ }^{1}$, Dave Chandler ${ }^{1}$, Jon Alcock ${ }^{1}$, Emily O'Donnell ${ }^{2}$, \\ Preeti Kaur $^{1}$, Elizabeth Bagshaw ${ }^{1}$, Martyn Tranter ${ }^{1}$, Andre Tedstone ${ }^{3}$, and Peter Nienow ${ }^{3}$ \\ ${ }^{1}$ Bristol Glaciology Centre, School of Geographical Sciences, University of Bristol, University Road, Bristol, BS8 1SS, UK \\ ${ }^{2}$ School of Geoscience, University of Edinburgh, Edinburgh, EH8 9XP, UK \\ ${ }^{3}$ School of Geography, University of Nottingham, NG7 2RD, UK
}

Correspondence to: Jemma Louise Wadham (j.1.wadham@bris.ac.uk)

Received: 21 September 2015 - Published in Biogeosciences Discuss.: 25 January 2016

Revised: 8 July 2016 - Accepted: 1 August 2016 - Published: 25 November 2016

\begin{abstract}
Fjord and continental shelf environments in the polar regions are host to some of the planet's most productive ecosystems and support economically important fisheries. Their productivity, however, is often critically dependent upon nutrient supply from upstream terrestrial environments delivered via river systems. In glacially fed coastal ecosystems, riverine nutrients are largely sourced from melting snow and ice. The largest and most extensive glacially fed coastal ecosystem in the Arctic is that bordering the Greenland Ice Sheet. The future primary productivity of this ecosystem, however, is uncertain. A potential increase in primary productivity driven by reduced sea ice extent and associated increased light levels may be curtailed by insufficient nutrient supply, and specifically nitrogen. Research on small valley glaciers indicates that glaciers are important sources of nitrogen to downstream environments. However, no data exist from ice sheet systems such as Greenland. Time series of nitrogen concentrations in runoff are documented from a large Greenland glacier, demonstrating seasonally elevated fluxes to the ocean. Fluxes are highest in mid-summer, when nitrogen limitation is commonly reported in coastal waters. It is estimated that approximately half of the glacially exported nitrogen is sourced from microbial activity within glacial sediments at the surface and bed of the ice sheet, doubling nitrogen fluxes in runoff. Summer dissolved inorganic nitrogen fluxes from the Greenland Ice Sheet $(30-40 \mathrm{Gg}$ ) are a similar order of magnitude to those from a large Arctic river (Holmes et al., 2012). Nitrogen yields from the ice sheet $\left(236 \mathrm{~kg} \mathrm{TDN} \mathrm{km}^{-2} \mathrm{a}^{-1}\right)$, however, are approximately double those from Arctic riverine catchments. We assert that this ice sheet nitrogen subsidy to Arctic coastal ecosystems may be important for understanding coastal biodiversity, productiv-
\end{abstract}

ity and fisheries and should be considered in future biogeochemical modelling studies of coastal marine productivity in the Arctic regions.

\section{Introduction}

The availability of nitrogen widely limits primary productivity in fjord (Rysgaard et al., 1999), coastal (Poulsen and Reuss, 2002; Daly et al., 1999; Nielsen and Hansen, 1999) and open ocean (Smith et al., 1985; Moore et al., 2002) waters bordering the Greenland Ice Sheet (GrIS) in summer. Hence, external sources of nitrogen to these waters, e.g. riverine runoff, may be important in sustaining the productivity of these waters and may alter in a warming climate. These Greenlandic waters are some of the most productive ecosystems in the world and boast high socio-economic value via fisheries (e.g. shrimp, halibut; Hamilton et al., 2000). In the North Atlantic, primary productivity also draws down $\mathrm{CO}_{2}$ from the atmosphere and has an important regulatory effect on global climate (Sabine et al., 2004). Warmer ocean temperatures and a lengthened growing season in the Arctic are predicted in future decades. However, increases in marine primary productivity may be capped by intensified summer nitrogen limitation (Vancoppenolle et al., 2013).

The GrIS discharges $>1000 \mathrm{~km}^{3}$ of freshwater annually to the Arctic Ocean, Irminger Sea, Labrador Sea and Greenland Sea (Bamber et al., 2012) but has yet to be evaluated as a source of nitrogen to these waters. This freshwater flux is increasing (Bamber et al., 2012), and will continue to do so as rising air and ocean temperatures enhance rates of ice sheet melting and iceberg calving (IPCC, 2007). Greenland 


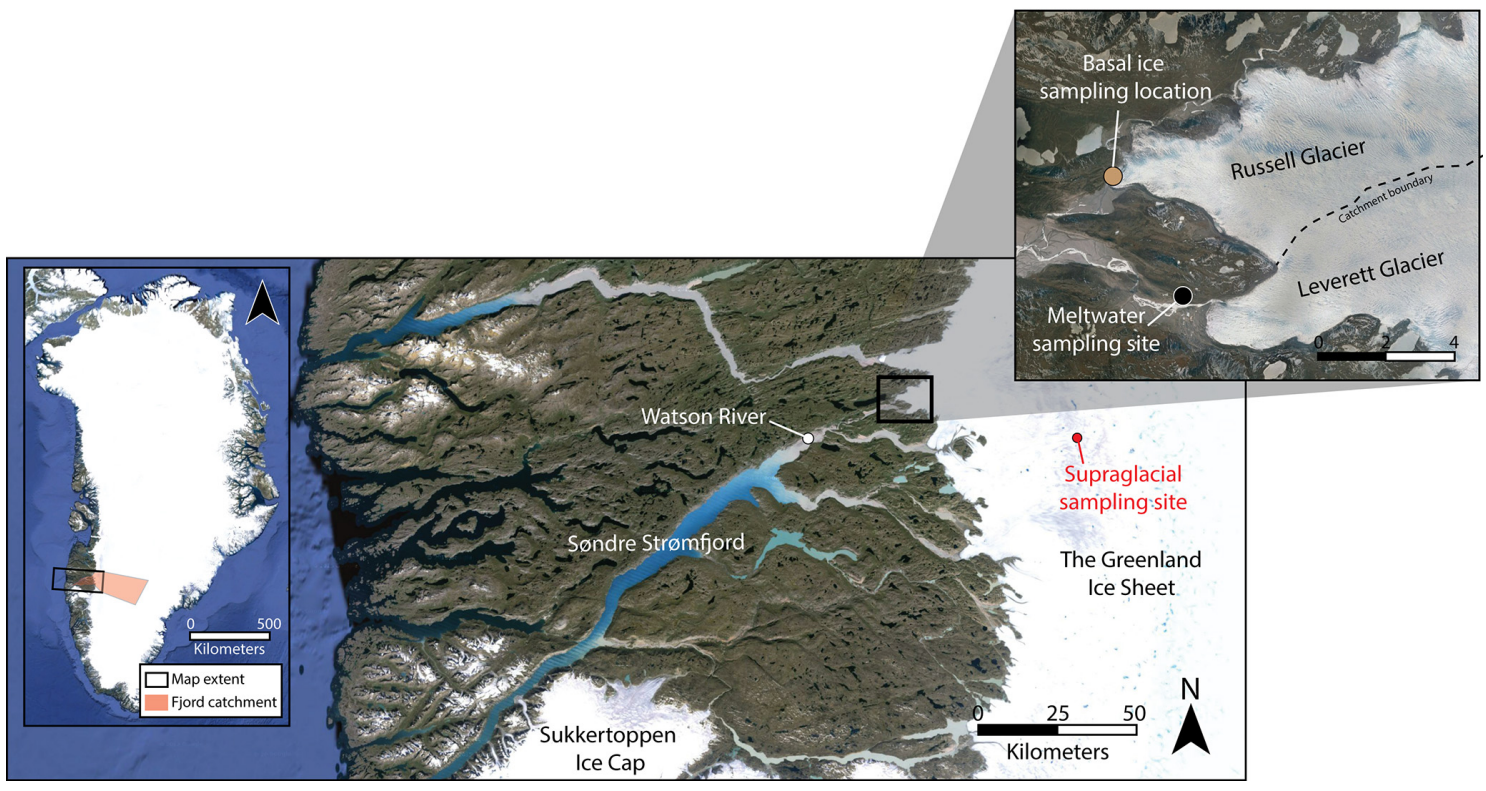

Figure 1. Map showing the study area, including the location of Leverett Glacier runoff sampling station (white dot), surface sampling site (red dot) and the basal ice sampling location (brown dot), together with Søndre Strømfjord and the Watson River, into which runoff from Leverett Glacier drains.

ice core data show the ubiquitous presence of low concentrations of dissolved inorganic nitrogen (DIN) in ice and snow, sourced from the atmosphere (Wolff, 2013). Based upon findings from small glacier systems (Hodson et al., 2008; Telling et al., 2011; Boyd et al., 2011), it is plausible that this atmospheric DIN is supplemented by nitrogen cycled into bioavailable forms by glacial biota (Telling et al., 2012; Boyd et al., 2011). While there is a mounting body of literature on nitrogen cycling on valley glaciers (Telling et al., 2011; Hodson et al., 2008), there is comparatively little data on nitrogen sources and cycling on the Greenland Ice Sheet, which is likely to be important as a nutrient source to downstream fjord and marine ecosystems. High reported rates of fjord primary productivity around the GrIS margin (Jensen et al., 1999) and coastal blooms as late as July/August (FrajkaWilliams and Rhines, 2010; Nielsen and Hansen, 1999) coincident with peak meltwater fluxes (Bartholomew et al., 2011) suggest that such an evaluation will be a fruitful exercise.

This article aims to examine the sources, cycling and fluxes of nitrogen and its component species in bulk runoff exported from the GrIS during the summer melt season. We document seasonal time series of nitrogen concentrations, speciation and fluxes associated with both surface meltwater and subglacial runoff at the large $\left(600 \mathrm{~km}^{2}\right)$ landterminating Leverett Glacier (LG) in SW Greenland during the 2012 melt season. This glacier has a bedrock (Precambrian gneiss/granite; Kalsbeek, 1982) that is consistent with large areas of the GrIS and covers a large altitudinal range, drawing meltwater from $>100 \mathrm{~km}$ from the ice margin. Hence, we assert that it is representative of large sectors of the Greenland margin. This article builds upon recent work by Hawkings et al. (2015), who presented a more limited dataset of dissolved inorganic subglacial nitrogen fluxes from the same catchment. We report data from a range of contextual field and experimental samples collected from sedimentladen ecosystems on and beneath the ice sheet (basal ice and incubated basal ice, glacier surface ice, snow, moulin and cryoconite waters) and subglacial incubation experiments in order to infer the relative importance of different sources of nitrogen species in runoff. Total dissolved nitrogen (TDN), DIN (nitrate and ammonium) and dissolved organic nitrogen (DON) were quantified in all samples, and exchangeable ammonium associated with suspended sediments $\left(\mathrm{SS}_{\mathrm{N}} \mathrm{NH}_{4}^{+}\right.$) was analysed in runoff. These data were used to calculate seasonal nitrogen fluxes and yields from the catchment, and subsequently similar estimates for the GrIS.

\section{Materials and methods}

\subsection{Field site}

Leverett Glacier is located on the south-west of the GrIS, approximately $300 \mathrm{~km}$ north of Nuuk (Fig $1 ; 67.06^{\circ} \mathrm{N}$, $50.10^{\circ} \mathrm{W}$ ). The glacier overlies predominantly Precambrian gneiss/granitic bedrock, typical of much of Greenland as indicated by geological surveys of the non-glaciated areas bordering the ice sheet (Kalsbeek, 1982; Kalsbeek and Taylor, 1984). The subglacial sediments are primarily Quaternary deposits (e.g. Palaeosols) containing fresh organic matter that were buried during glacial advance in the last few 
thousands of years following the Holocene Thermal Maximum when the GrIS margin was positioned tens of kilometres further inland (Simpson et al., 2009). LG supplies runoff to the Watson River during the summer months, the largest of three glacially fed rivers which supply Søndre Strømfjord (Fig. 1). Søndre Strømfjord is the largest fjord system in western Greenland and comprises an inner fjord (up to $275 \mathrm{~m}$ deep, $4 \mathrm{~km}$ wide and $80 \mathrm{~km}$ long) and a shallow outer fjord ( $<100 \mathrm{~m}$ deep, $1 \mathrm{~km}$ wide and $100 \mathrm{~km}$ long; Nielsen et al., 2010). The inner fjord physical oceanography is influenced by meltwater, as indicated by a $50-75 \mathrm{~m}$ freshwater surface layer (Nielsen et al., 2010).

\subsection{Sample collection, processing and storage}

Two main sampling sites were established in summer 2012: one at the ice sheet margin (11 May-15 July) $1 \mathrm{~km}$ downstream of the glacier terminus (glacial runoff sampling site, Fig. 1, black dot) and one on the ice sheet surface (8 May- 8 August) at a moulin located approximately $35 \mathrm{~km}$ from the ice margin (surface meltwater sampling site, Fig. 1, red dot).

\subsubsection{Ice sheet surface sampling}

A field camp was established in 2012 in the mid-ablation zone at LG at $1030 \mathrm{~m}$ elevation, $35 \mathrm{~km}$ from the western margin $\left(66.97^{\circ} \mathrm{N}, 049.27^{\circ} \mathrm{W}\right)$. Here, samples of meltwater descending to the ice sheet bed (Chandler et al., 2013) were collected from the streams feeding a large moulin between 5 May and 9 August (Day 129 and 222). The discharge of meltwater into this moulin was also measured (Supplement Sect. S1). A range of contextual samples were collected, including ice containing dispersed cryoconite debris (referred to here as "summer ice") and cryoconite hole waters. Cryoconite holes are water-filled cylindrical melt holes, formed by radiation heating of surface sediment and subsequent melting (Podgorny and Grenfell, 1996). The debris in the base of these holes is termed "cryoconite", which may become distributed over the glacier surface during meltout of cryoconite holes in summer. Ice samples were melted in clean/sterile Whirl-pak ${ }^{\mathrm{TM}}$ bags (Nasco) overnight in a warm water bath immediately after collection (melting typically took 2-3 h). All meltwater samples were filtered through $47 \mathrm{~mm}, 0.45 \mu \mathrm{m}$ cellulose nitrate filters (Whatman ${ }^{\mathrm{TM}}$ ) in a plastic filter unit (Nalgene ${ }^{\mathrm{TM}}$ PES), pre-rinsed three times with sample and stored in high density polyethylene plastic bottles (Nalgene ${ }^{\mathrm{TM}}$; $30 \mathrm{~mL}$ ). Samples were frozen immediately after filtration and only thawed out immediately prior to analysis in Bristol. Procedural blanks were processed $(n=5)$ during the course of the sampling season, where deionized water (stored in clean plastic bottles) was treated as a sample.

\subsubsection{Bulk meltwater sampling}

The river draining from the subglacial portal at LG was continuously monitored during the 2012 melt season (MayOctober) using stage measurements in a stable bedrock section $\sim 2.2 \mathrm{~km}$ downstream of the terminus (Hawkings et al., 2014, 2015, 2016; Cowton et al., 2012; Tedstone et al., 2013). Stage was logged every 5-10 min and converted to discharge using rhodamine dye-dilution experiments $(>30$ dye tracing experiments were carried out over the season using standard methods; Cowton et al., 2013). The error in measured discharge determinations is $\pm 10 \%$ (Tedstone et al., 2013). Suspended sediment concentrations were calculated as in previous work from bulk meltwater turbidity measurements (Cowton et al., 2012). A turbidity sensor was employed throughout the monitoring period in a similar location to stage measurements. The sensor was calibrated using manual sediment weight samples. Briefly, a recorded amount of meltwater (usually $300 \mathrm{~mL}$ ) was filtered through a $0.45 \mu \mathrm{m}$ cellulose nitrate filter (Whatman ${ }^{\mathrm{TM}}$ ), oven-dried overnight at $40^{\circ} \mathrm{C}$ and weighed.

Bulk meltwater samples were taken approximately $1 \mathrm{~km}$ downstream from the LG subglacial portal, at least once a day during the main melt period (May-July). Samples were collected daily at $\sim 10: 00$, with occasional additional afternoon samples taken at $\sim 18: 00$, mostly during subglacial outburst events. A $2 \mathrm{~L}$ meltwater grab sample was taken in a HDPE Nalgene ${ }^{\mathrm{TM}}$ bottle (Thermo Scientific ${ }^{\mathrm{TM}}$ ), which had been pre-rinsed three times in the meltwater stream. Samples were filtered soon after collection using a Nalgene ${ }^{\mathrm{TM}}$ reusable PES filtration stack, and a $47 \mathrm{~mm} 0.45 \mu \mathrm{m}$ cellulose nitrate filter membrane $\left(\right.$ Whatman $^{\mathrm{TM}}$ ). Filtered samples were stored in $28 \mathrm{~mL}$ HDPE bottles. Procedural blanks were processed $(n=10)$ during the course of the sampling season, where deionized water (stored in clean Nalgene ${ }^{\mathrm{TM}}$ HDPE plastic bottles) was treated as a sample and filtered and bottled accordingly. All samples were immediately frozen and stored in the dark until analysis in Bristol.

\subsubsection{Basal ice sampling and incubation experiments}

Basal ice from the Leverett-Russell Glacier catchment was collected by chainsaw from an easily accessible outcrop of debris-rich basal ice at the ice margin (within $5 \mathrm{~km}$ of the main LG bulk meltwater sampling site, Fig. 1) $(30 \times 30 \times 30 \mathrm{~cm}$ blocks $)$ in spring 2008 and summer 2010 . The outermost $\sim 0.5 \mathrm{~m}$ of ice was first removed before the blocks were cut. The blocks were wrapped in large sheets of pre-combusted foil and stored at $\leq-20^{\circ} \mathrm{C}$ prior to processing. Sub-samples of the ice were prepared for nitrogen analysis by chipping $\sim 15 \times 15 \times 5 \mathrm{~cm}$ chunks from the main block using a flame-sterilized chisel. The outer $\sim 10-30 \mathrm{~mm}$ was removed by rinsing with ultrapure $\left(\geq 18.2 \mathrm{M} \Omega \mathrm{cm}^{-1}\right)$ deionized water, and the remaining ice was transferred into a pre-combusted glass beaker covered with foil. The ice was 
allowed to melt inside a laminar flow cabinet (Telstar Mini$\mathrm{H})$ at room temperature. Ice melt was filtered through Whatman polypropylene Puradisc ${ }^{\mathrm{TM}} 0.45 \mu \mathrm{m}$ syringe filters. Samples for nitrogen species determinations were stored in clean, thrice-rinsed Nalgene ${ }^{\mathrm{TM}}$ HDPE bottles. All sediment and filtered samples were stored in the dark at $\leq-20^{\circ} \mathrm{C}$ until analytical processing.

Long-term incubation experiments ( $>1$ year) were conducted using sediment and meltwater derived from melted basal ice samples, in order to investigate microbially derived sources of dissolved nitrogen in a simulated subglacial environment. Three types of experiments were conducted: (1) live control experiment with no sediment added, where the solution was meltwater from basal ice; (2) live anaerobic experiments (sediment + meltwater from basal ice); and (3) live aerobic experiments (sediment + meltwater from basal ice). The control sediment-free experimental nitrogen concentrations were subtracted from the live (sediment + water) experiments in order to correct for nitrogen species added from the sampling vessel and the original basal ice meltwater matrix. Hence, nitrogen concentrations reported are those that have evolved during the experiment via rock-water contact and in situ microbial activity.

Experiments were performed in the dark at $0.1{ }^{\circ} \mathrm{C}$ in modified gas-tight $500 \mathrm{~mL}$ borosilicate glass bottles. A sampling port towards the base of the vessel immediately above the sediment surface was used for water extraction. All incubations contained $100 \mathrm{~mL}$ of wet-weight sediment, $200 \mathrm{~mL}$ meltwater and $200 \mathrm{~mL}$ gas headspace. Control incubation experiments contained $200 \mathrm{~mL}$ ice melt only. Sediment and ice melt (flushed with $\mathrm{O}_{2}$-free $\mathrm{N}_{2}$ gas) required for the anaerobic incubations were melted inside a glove bag filled with $\mathrm{O}_{2}$ free $\mathrm{N}_{2}$ gas (BOC Ltd, UK). Meltwater and sediments were later flushed with $\mathrm{O}_{2}$-free $\mathrm{N}_{2}$ gas for $>20$ min to ensure that the sediment and water were equilibrated with an oxygenfree atmosphere. The incubations were sampled $\sim 2 \mathrm{~h}$ after set-up ( $T=0$ days), on day 4, 109, 190, 294, 382, 533 and 758 (aerobic only). At each sampling point, $30 \mathrm{~mL}(15 \%$ of the initial volume) of meltwater was removed, filtered through Whatman polypropylene Puradisc ${ }^{\mathrm{TM}} 0.45 \mu \mathrm{m}$ syringe filters and stored at $\leq-20^{\circ} \mathrm{C}$ until analysis. Sampling of the anaerobic incubation experiments were conducted inside a glove bag filled with $\mathrm{O}_{2}$-free $\mathrm{N}_{2}$ gas. All meltwater samples were frozen immediately after collection and stored frozen prior to analysis for dissolved nitrogen species.

\subsection{Analytical methods}

All meltwater samples were analysed for concentrations of total dissolved nitrogen (TDN) and dissolved inorganic nitrogen (DIN, comprising nitrate and ammonium), with dissolved organic nitrogen (DON) determined by the difference between TDN and DIN. Concentrations of nitrite were generally below the limit of detection and are not reported. We also analysed ammonium concentrations associated with sus- pended sediments in runoff $\left(\mathrm{SS}_{\mathrm{N}} \mathrm{NH}_{4}^{+}\right)$, where this component is assumed to be bioavailable. The nitrogen content of snow is taken from previous work conducted in the same catchment (Telling et al., 2012) and from Greenland ice cores (Wolff, 2013). Pre-melt surface glacier ice nitrogen concentrations were taken from previous work conducted in Leverett Glacier catchment (Telling et al., 2012). The detailed sampling and analytical procedures are provided in the following sections.

\subsubsection{Nitrate}

Nitrate was determined using a Thermo Scientific $^{\mathrm{TM}}$ Dionex $^{\mathrm{TM}}$ ICS-5000 ion chromatograph fitted with an IonPac $^{\mathrm{TM}}$ AS11-HC-4 $\mu \mathrm{m}$ anion-exchange column. A $30 \mathrm{mM}$ $\mathrm{KOH}$ eluent concentration was used, with an injection volume of $0.4 \mu \mathrm{L}$ and cell temperature of $35^{\circ} \mathrm{C}$. The detection limit of the instrument was $0.08 \mu \mathrm{MN}$. The precision of analyses, determined via analysis of 11 replicate standards at the lower end of the sample range $(1.6 \mu \mathrm{M})$, was $8.1 \%$. The accuracy of the machine was determined as $-6.4 \%$, using gravimetrically weighed standards from a $1000 \mathrm{mg} \mathrm{L}^{-1}$ certified stock standard (Sigma TraceCERT ${ }^{\circledR}$ ). All field nitrate data were blank-corrected using field procedural blanks. The nitrate concentrations within these blanks were $<0.45 \mu \mathrm{M}$ for surface samples and below the detection limit for runoff samples.

\subsubsection{Ammonium}

Ammonium was determined manually using the salicylate spectrophotometric method (Bower and Holm-Hansen, 1980; Le and Boyd, 2012), adapted for a smaller sample size $(1 \mathrm{~mL})$. The detection limit of the method was $0.6 \mu \mathrm{MN}$. The precision of analyses was $4.9 \%$, calculated from five replicate standards $(1.8 \mu \mathrm{M})$. Accuracy was calculated to be $+0.3 \%$ (from a gravimetrically diluted certified reference standard, Sigma-Aldrich TraceCERT(R) $1000 \mathrm{mg} \mathrm{L}^{-1}$ ). Ammonium concentrations in field samples were blankcorrected using field procedural blanks and were all above the limit of detection. Mean blank correction factors for ammonium were $0.75 \mu \mathrm{MN}$ for surface samples. Runoff blank corrections were below the detection limit of the instrument.

\subsubsection{Total dissolved nitrogen (TDN)}

Total nitrogen was determined on runoff samples using a Lachat QuikChem ${ }^{\circledR} 8500$ Flow Injection Analyser system, with digestion unit (method number 10-107-04-3-E). The detection limit of the instrument was $1.4 \mu \mathrm{M} \mathrm{TDN}$; the precision of analyses was calculated as $11.3 \%$ from six $3.6 \mu \mathrm{M}$ replicate reference standards (gravimetrically diluted from a certified reference standard, Sigma-Aldrich TraceCERT(R) $1000 \mathrm{mg} \mathrm{L}^{-1}$ ). Accuracy was determined using the same reference standards as $-0.4 \%$. All TDN data were field-blankcorrected $(2 \mu \mathrm{M}$ for surface samples, and no correction for 
Table 1. Mean concentrations of nitrogen species reported in LG runoff (including discharge weighted mean, DWM for TDN species), in comparison to those in moulin waters, surface ice (pre-melt and post-melt "summer ice", where the latter samples were at the melting temperature and contained dispersed debris), snow, cryoconite water and basal ice.

\begin{tabular}{|c|c|c|c|c|c|c|c|c|c|c|c|c|c|c|c|}
\hline & \multicolumn{3}{|c|}{$\mathrm{NO}_{3}^{-}(\mu \mathrm{M})$} & \multicolumn{3}{|c|}{$\mathrm{NH}_{4}^{+}(\mu \mathrm{M})$} & \multicolumn{3}{|c|}{$\mathrm{DIN}(\mu \mathrm{M})$} & \multicolumn{3}{|c|}{$\mathrm{DON}(\mu \mathrm{M})$} & \multicolumn{3}{|c|}{$\mathrm{TDN}(\mu \mathrm{M})$} \\
\hline & mean & SD & $n$ & mean & SD & $n$ & mean & SD & $n$ & mean & $\mathrm{SD}$ & $n$ & mean & SD & $n$ \\
\hline Bulk runoff - dissolved & 1.8 & 1.2 & 62 & 0.4 & 0.6 & 62 & 2.2 & 1.4 & 62 & 2.3 & 1.5 & 62 & 4.5 & 2.3 & 62 \\
\hline Bulk runoff - dissolved, DWM & 1.1 & - & - & 0.3 & - & - & 1.4 & - & - & 1.7 & - & - & 3.2 & - & - \\
\hline Bulk runoff-sediment-bound & n.d. & n.d. & - & 1.2 & 0.6 & 39 & 1.2 & n.d. & - & n.d. & n.d. & - & 1.2 & n.d. & - \\
\hline Bulk runoff-sediment-bound DWM & n.d. & n.d. & - & 1.4 & - & 39 & n.d. & n.d. & - & n.d. & n.d. & - & n.d. & n.d. & - \\
\hline Moulins (same time period) & 0.7 & 1.4 & 28 & 0.6 & 0.5 & 28 & 2.0 & 1.2 & 28 & 1.1 & 1.3 & 28 & 2.2 & 1.4 & 28 \\
\hline \multicolumn{16}{|l|}{ Surface } \\
\hline Pre-melt ice ${ }^{\mathrm{a}}$ & 0.59 & 0.14 & 6 & 0.3 & 0.1 & 6 & 0.9 & 0.3 & 6 & 0.0 & 0.0 & 6 & 0.6 & 0.1 & 6 \\
\hline Snow ${ }^{\mathrm{a}}$ & 1.03 & 0.17 & 3 & 0.45 & 0.0 & 3 & 1.4 & 0.2 & 3 & 0.0 & 0.0 & 3 & 1.02 & 0.14 & 3 \\
\hline GrIS ice cores ${ }^{\mathrm{b}}$ & 0.97 & n.d. & - & 0.45 & n.d. & - & 1.4 & n.d. & - & n.d. & n.d. & - & n.d. & n.d. & - \\
\hline Summer ice & 0.64 & 0.42 & 7 & 0.6 & 0.6 & 7 & 1.3 & 0.9 & 7 & 3.0 & 2.6 & 7 & 2.9 & 2.1 & 7 \\
\hline Cryoconite meltwater & 1.4 & 0.4 & 6 & 1.1 & 1.3 & 6 & 1.7 & 0.9 & 6 & 0.7 & 0.4 & 6 & 2.4 & 1.1 & 6 \\
\hline \multicolumn{16}{|l|}{ Subglacial } \\
\hline Basal ice & 1.5 & 0.0 & 6 & 2.7 & 0.1 & 6 & 3.7 & 0.1 & 6 & 12 & 1.3 & 6 & 15 & 1.3 & 6 \\
\hline Incubations (aerobic) & 1.4 & 2.1 & 7 & 2.5 & 2.2 & 7 & 3.9 & 2.5 & 7 & 3.4 & 2.0 & 7 & 7.1 & 1.7 & 7 \\
\hline Incubations (anaerobic) & 1.0 & 1.4 & 6 & 0.8 & 0.2 & 6 & 1.8 & 1.3 & 6 & 1.8 & 1.0 & 6 & 5.3 & 1.4 & 6 \\
\hline
\end{tabular}

a Telling et al. (2012). ${ }^{\mathrm{b}}$ Wolff (2013).

runoff samples since these were below the detection limit of the instrument).

\subsubsection{Exchangeable $\mathrm{NH}_{4}^{+}$in suspended sediment $\left(\mathrm{SS}-\mathrm{NH}_{4}^{+}\right.$)}

Measurements were conducted using the method described by Maynard et al. (2007). Filters containing suspended solids were placed into polypropylene centrifuge tubes, and the $\mathrm{NH}_{4}^{+}$was then extracted with $10 \mathrm{~mL}$ of $2 \mathrm{M} \mathrm{KCl}$ for $30 \mathrm{~min}$ on an automatic shaking table $(160 \mathrm{rpm})$. Extracts were decanted into additional centrifuge tubes, centrifuged at $4500 \mathrm{rpm}$ for $5 \mathrm{~min}$, and filtered through $0.45 \mu \mathrm{m}$ inline Whatman ${ }^{\circledR}$ polypropylene Puradisc filters. When immediate analysis was not possible, they were immediately frozen $\left(-20^{\circ} \mathrm{C}\right)$ until analysis. A second sequential extraction was then performed to extract any residual sediment-bound $\mathrm{NH}_{4}^{+}$. Extracts were analysed on a Bran and Luebbe Autoanalyzer 3 , with a detection limit in extracts of $0.9 \mu \mathrm{MN}$, equivalent to $0.09 \mu \mathrm{MN}$ for a typical sediment mass of $0.1 \mathrm{~g}$. The $\mathrm{NH}_{4}^{+}$concentrations from the first and second extracts were combined to give a total $\mathrm{NH}_{4}^{+}$for the suspended sediment samples. Dry weights for sediment samples were obtained by washing residual sediment from filters into centrifuge tubes with Milli-Q water, centrifuging at $4500 \mathrm{rpm}$ for $5 \mathrm{~min}$, then repeating with a further Milli-Q wash and centrifuging stage to remove any residual $\mathrm{KCl}$. Sediments were then ovendried (overnight at $40^{\circ} \mathrm{C}$ ) and weighed. This gave concentrations of exchangeable $\mathrm{NH}_{4}^{+}$of $\mu \mathrm{mg} \mathrm{N} \mathrm{g}^{-1}$, which were converted into units of $\mu \mathrm{MN} \mathrm{g}^{-1}$ and then to $\mu \mathrm{MN}$ by multiply- ing by the instantaneous suspended sediment concentration (in $\mathrm{g} \mathrm{L}^{-1}$ ) at the time of sample collection. $\mathrm{SS}^{-\mathrm{NH}_{4}^{+}}$fluxes $\left(\mu \mathrm{MN} \mathrm{s}^{-1}\right)$ were subsequently calculated from the product of the $\mathrm{NH}_{4}^{+}$concentration and bulk discharge (in L) at the time of sample collection.

\subsection{Flux calculations}

\subsection{Nitrogen fluxes from Leverett Glacier}

Nitrogen fluxes (May-September) are calculated for LG for the 2012 melt season, which was a record melt year in Greenland (Tedesco et al., 2013). Discharge weighted mean concentrations of dissolved nitrogen species and $\mathrm{SS}_{-} \mathrm{NH}_{4}^{+}$for LG runoff were calculated for the 2012 melt season. Use of discharge weighted mean (DWM) concentrations lowers the mean nitrogen concentrations in bulk meltwater, since high discharge values are generally accompanied by low nitrogen concentrations. Hence, this method provides a more conservative estimate of nitrogen fluxes. We use minimum and maximum concentrations of nitrogen species to illustrate the potential maximum range of nitrogen fluxes under different hydro-climatological regimes. The product of the DWM, minimum and maximum concentration of each nitrogen species and the runoff flux for the summer discharge monitoring period in 2012 from LG $\left(2.2 \mathrm{~km}^{3}\right.$, Supplement Fig. S5) generated the total seasonal fluxes of these nitrogen species. We did not measure the particulate organic nitrogen $(\mathrm{PON})$ concentrations in runoff, and in previous years these concentrations have been below the detection limit of standard analytical methods. However, we did calculate the 

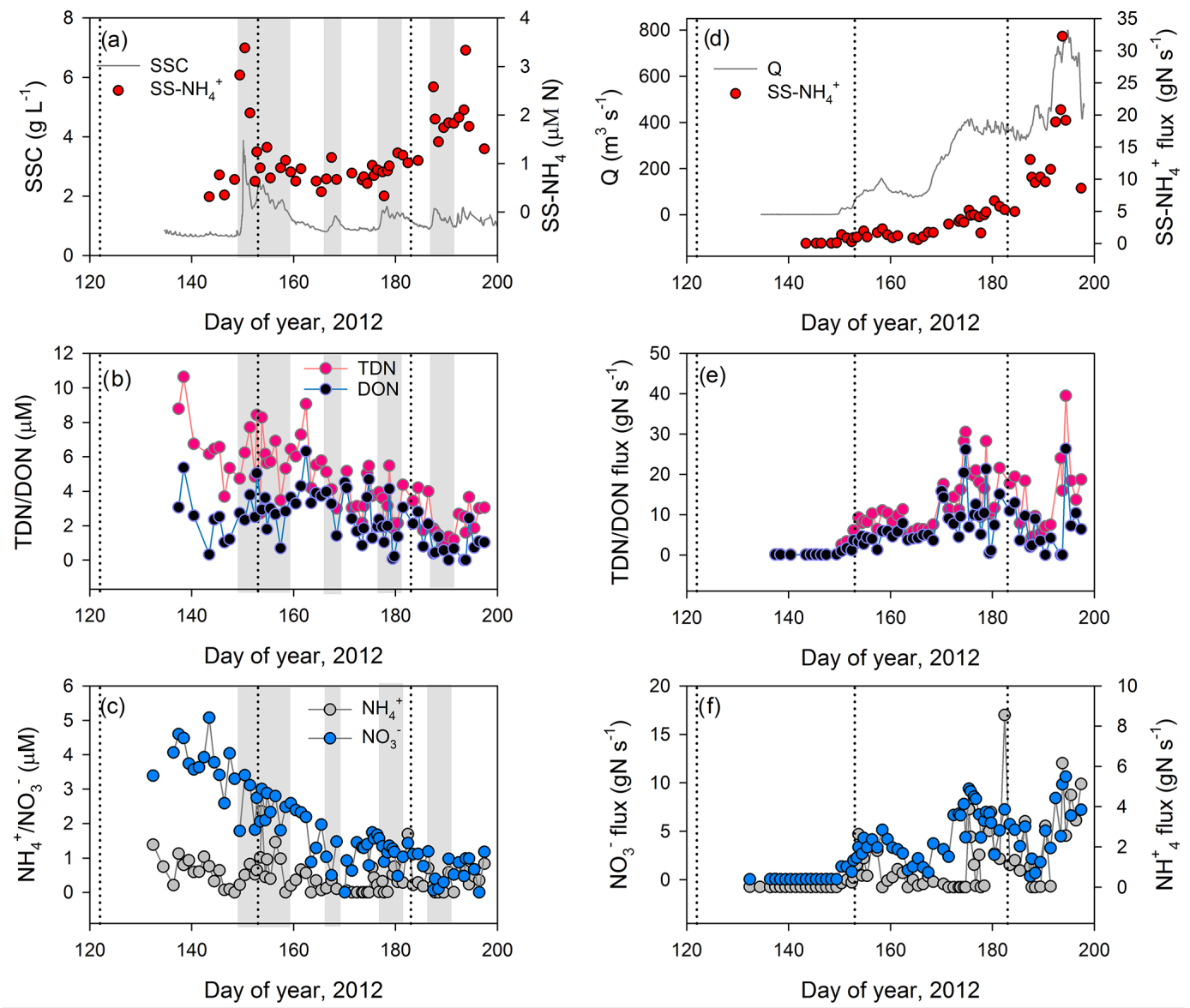

Figure 2. Times series of nitrogen species in LG runoff from the 2012 melt season depicting concentrations of (a) bulk meltwater suspended sediment and sediment-bound ammonium $\left(\mathrm{SS}-\mathrm{NH}_{4}^{+}\right.$; b) TDN and DON, (c) dissolved nitrate and ammonium, and instantaneous fluxes of (d) $\mathrm{SS}_{-} \mathrm{NH}_{4}^{+}$(bulk meltwater discharge, $Q$, is also shown), (e) TDN and DON, and (f) dissolved nitrate and ammonium. Vertical dotted lines (left to right) indicate 1 May, 1 June and 1 July 2012. The grey shaded bars reflect inferred subglacial outburst events (Hawkings et al., 2014).

SS- $\mathrm{NH}_{4}^{+}$fluxes in the same manner as the dissolved nitrogen species. Total fluxes of dissolved and SS- $\mathrm{NH}_{4}^{+}$in LG runoff during the 2012 melt season are presented in Table 2. Errors on these estimates due to discharge uncertainty and catchment area are of the order of \pm 10 and $\pm 25 \%$ respectively (Tedstone et al., 2013; Cowton et al., 2012), giving a combined uncertainty of $\pm 27 \%$.

\subsubsection{Nitrogen fluxes from the Greenland Ice Sheet}

Currently, there are no other seasonal time series of nitrogen concentrations in runoff from large Greenland outlet glaciers. Hence, nitrogen concentrations in LG runoff are used in order to generate order of magnitude flux estimates for nitrogen associated with Greenland freshwater export. We base our calculations upon the premise that LG is representative of large areas of the GrIS, for several reasons. First, LG displays a high altitudinal range (250-1510 $\mathrm{m}$ a.s.l.) and extends for $>80 \mathrm{~km}$ inland, like many large Greenland outlets. Hence, nitrogen supply from snow and ice melt are likely to be representative of other large catchments draining the ice sheet. Second, microbial processes (e.g. nitrogen fixation, nitrification, organic matter mineralization), which are thought to generate approximately half of the ice sheet nitrogen in runoff (via DON, nitrate and ammonium), are reported from a wide range of other glacial systems worldwide, including the Greenland Ice Sheet (Hodson et al., 2005; Boyd et al., 2011; Telling et al., 2012), a reflection of the ubiquitous nature of microbial ecosystems upon glacier surfaces and at glacier beds. Third, the bedrock geology at LG is representative of large areas of the GrIS (see Sect. 2.1). This suggests that the drivers for nitrogen export at Leverett Glacier are likely to be applicable to other large catchments, which account for the bulk of the freshwater flux from the ice sheet to the oceans. Our approach is widely employed for calculating solute fluxes from ice sheet systems where datasets are sparse due to the difficulty of making measurements (Wadham et al., 2010; Bhatia et al., 2013; Lawson et al., 2014a; Hawkings et al., 2014, 2016). 
Table 2. Estimates of seasonal fluxes of total dissolved (TDN) and particulate nitrogen ( $\mathrm{SS}-\mathrm{NH}_{4}^{+}$) species (total nitrogen - TN) from Leverett Glacier in 2012. Values marked with an asterisk were below the detection limit. Hence, the minimum concentration is set to the detection limit of the instrument.

\begin{tabular}{|c|c|c|c|c|c|c|c|}
\hline \multicolumn{8}{|l|}{ Glacial runoff: Leverett Glacier (LG) } \\
\hline LG water flux $\left(\mathrm{km}^{3} \mathrm{a}^{-1} ; 2012\right)^{\mathrm{a}}$ & 2.2 & & & & & & \\
\hline Concentration LG $(\mu \mathrm{M})$ & TDN & DIN & DON & $\mathrm{NO}_{3}^{-}-\mathrm{N}$ & $\mathrm{NH}_{4}^{+}-\mathrm{N}$ & $\mathrm{SS}-\mathrm{NH}_{4}^{+}-\mathrm{N}$ & $\mathrm{TN}+\mathrm{SS}-\mathrm{NH}_{4}^{+}$ \\
\hline $\min$ & $1.4^{*}$ & 0.5 & 0.1 & 0.1 & $0.6^{*}$ & 0.31 & 1.2 \\
\hline DWM & 3.2 & 1.5 & 1.7 & 1.1 & 0.3 & 1.4 & 4.6 \\
\hline $\max$ & 11 & 7.5 & 6.3 & 5.1 & 2.4 & 3.7 & 15 \\
\hline Flux LG $\left(\mathrm{ta}^{-1}\right): 2012$ & TDN & DIN & DON & $\mathrm{NO}_{3}^{-}-\mathrm{N}$ & $\mathrm{NH}_{4}^{+}-\mathrm{N}$ & $\mathrm{SS}-\mathrm{NH}_{4}^{+}-\mathrm{N}$ & $\mathrm{TN}+\mathrm{SS}-\mathrm{NH}_{4}^{+}$ \\
\hline $\min$ & 43 & 15 & 3 & 3 & 18 & 10 & 53 \\
\hline DWM & 99 & 46 & 52 & 34 & 9 & 43 & 142 \\
\hline $\max$ & 339 & 231 & 194 & 157 & 74 & 114 & 453 \\
\hline Yield, using DWM $\left(\mathrm{kg} \mathrm{N} \mathrm{km}^{2} \mathrm{a}^{-1}\right)$ & 164 & 77 & 87 & 56 & 15 & 72 & 236 \\
\hline
\end{tabular}

Fluxes of nitrogen from the GrIS are calculated from the product of DWM, minimum and maximum concentrations of the different nitrogen species at LG glacier (Table 3) and the total ice sheet runoff flux for 2012 and the mean runoff flux of 2000-2011 (Tedesco et al., 2013; Table 3). The latter is modelled using the MAR regional climate model. Errors for meltwater runoff determinations via the MAR model are estimated at $10 \%$ (Vernon et al., 2013). Hence, we might expect similar uncertainty to propagate to nutrient flux determinations. We also estimate the potential nitrogen fluxes exported to the ocean by iceberg calving, which have a potential farfield influence within the open ocean (Syvitski et al., 2001; Smith Jr. et al., 2013). Iceberg nitrogen fluxes are taken to be the product of the iceberg freshwater flux and mean nitrogen concentrations in Greenland ice cores (Table 3). We employ a freshwater flux for Greenland icebergs of $600 \mathrm{~km}^{3} \mathrm{a}^{-1}$, based upon approximate average values for the last decade (Bamber et al., 2012). We assume that the mean concentrations of nitrogen in icebergs are similar to those reported in Greenland ice cores (Wolff, 2013), which are also in line with those reported in LG catchment (Telling et al., 2012). This is a conservative estimate, since additional nitrogen supply is likely associated with sediments entombed within icebergs. Results from this work indicate that the SS-NH $\mathrm{NH}_{4}$ content of ice containing even trace amounts of debris may display elevated nitrogen concentrations which are 5 times higher than in ice with no debris (Table 1).

\section{Results and discussion}

\subsection{Sources of nitrogen in runoff}

The LG runoff time series demonstrates that the GrIS provides a continuous supply of nitrogen to downstream ecosys- tems throughout the main melt period (Fig. 2). Concentrations of TDN are significant $(1-10 \mu \mathrm{M})$ and mean nitrate concentrations $(1.8 \mu \mathrm{mM})$ alone are higher than those reported in surface ocean and fjord waters $(<0.1-1 \mu \mathrm{M})$ in western Greenland in summer (Nielsen and Hansen, 1999; Arendt et al., 2010; Hopwood et al., 2016). Higher concentrations of nitrate are observed in deeper ocean waters, but upward diffusion and advection are often limited by a stratified water column during the summer months (Arendt et al., 2010). DIN, which is readily available to marine phytoplankton, accounts for half of the TDN in LG runoff, supplemented by SS-NH ${ }_{4}^{+}$from the ice sheet bed. A component $(\sim 50 \%)$ of the DIN measured in LG runoff originates from natural and anthropogenic atmospheric sources, via melting of snow and ice (Wolff, 2013; Table 1). LG drains a large catchment (active hydrological catchment area $=600 \mathrm{~km}^{2} \pm 25 \%$; Cowton et al., 2012) with a high altitudinal range (extending to $>1500 \mathrm{~m}$ a.s.l.). New moulins open up and surface lakes drain with snow line retreat (Bartholomew et al., 2011), providing a mechanism by which new sources of DIN are fed to runoff. Water fluxes control the overall nitrogen flux, which rises through summer to attain high values during the sampling period in mid-July (Fig. 2). The bulk runoff chemical sampling record did not extend beyond this point. However, we assert that runoff nitrogen fluxes will continue to be high in late July-early August, as evidenced by the sustained high fluxes of nitrogen species in moulin waters up until 9 August (Day 222, Fig. S5). This is significant given the reported nitrogen limitation of fjord and marine phytoplankton in midsummer, once the water column becomes more stratified and deep marine sources of nitrogen become more inaccessible (Rysgaard et al., 1999; Budeus and Schneider, 1995).

A striking feature of the runoff dataset is the factor of 4 increase in concentrations of TDN in LG runoff $(4.5 \mu \mathrm{mM}$, 
Table 3. Estimates of seasonal fluxes of total dissolved (TDN) and particulate nitrogen $\left(\mathrm{SS}-\mathrm{NH}_{4}^{+}\right)$species (total nitrogen - TN) from the Greenland Ice Sheet in 2000-2010 and 2012.

\begin{tabular}{|c|c|c|c|c|c|c|c|}
\hline \multicolumn{8}{|l|}{ Glacial runoff: Greenland Ice Sheet } \\
\hline GrIS water flux $\left(\mathrm{km}^{3} \mathrm{a}^{-1} ; 2000-2011\right)^{\mathrm{a}}$ & 418 & & & & & & \\
\hline \multirow{2}{*}{ GrIS water flux $\left(\mathrm{km}^{3} \mathrm{a}^{-1} ; 2012\right)^{\mathrm{a}}$} & 665 & & & & & & \\
\hline & TDN & DIN & DON & $\mathrm{NO}_{3}^{-}-\mathrm{N}$ & $\mathrm{NH}_{4}^{+}-\mathrm{N}$ & $\mathrm{SS}-\mathrm{NH}_{4}^{+}-\mathrm{N}$ & $\mathrm{TN}+\mathrm{SS}-\mathrm{NH}_{4}^{+}$ \\
\hline \multicolumn{8}{|l|}{ Flux GrIS $\left(\mathrm{Gg} \mathrm{a}^{-1}\right):$ 2000-2010 } \\
\hline Min & 5.3 & 3 & 1 & 1 & 2 & 2 & 7.1 \\
\hline DWM & 19 & 9 & 10 & 6 & 2 & 8 & 27 \\
\hline $\operatorname{Max}$ & 64 & 44 & 37 & 30 & 14 & 22 & 86 \\
\hline \multicolumn{8}{|l|}{ Flux GrIS $\left(\mathrm{Gg} \mathrm{a}^{-1}\right): 2012$} \\
\hline Min & 8.4 & 4.7 & 0.9 & 0.9 & 3.7 & 2.9 & 11 \\
\hline DWM & 30 & 14 & 16 & 10 & 2.8 & 13 & 43 \\
\hline Max & 102 & 70 & 59 & 47 & 22 & 34 & 137 \\
\hline \multicolumn{8}{|l|}{ Ice discharge Greenland Ice Sheet } \\
\hline \multirow[t]{2}{*}{ GrIS iceberg discharge $\left(\mathrm{km}^{3} \mathrm{a}^{-1}\right)^{\mathrm{a}}$} & $\sim 600$ & & & & & & \\
\hline & TDN & DIN & DON & $\mathrm{NO}_{3}^{-}-\mathrm{N}$ & $\mathrm{NH}_{4}^{+}-\mathrm{N}$ & $\mathrm{SS}-\mathrm{NH}_{4}^{+}-\mathrm{N}$ & $\mathrm{TN}+\mathrm{SS}-\mathrm{NH}_{4}^{+}$ \\
\hline Mean concentration $(\mu \mathrm{M})$ & 1.4 & 1.4 & 0 & 0.97 & 0.45 & $\mathrm{n} / \mathrm{a}$ & 1.4 \\
\hline Flux $\left(\mathrm{Gg} \mathrm{a}^{-1}\right)$ & 12 & 12 & 0.0 & 8 & 4 & $\mathrm{n} / \mathrm{a}$ & 12 \\
\hline \multicolumn{8}{|l|}{ Arctic river discharge } \\
\hline \multirow{2}{*}{ Arctic river mean summer water flux $\left(\mathrm{km}^{3} \mathrm{a}^{-1}\right)^{\mathrm{b}}$} & 169 & & & & & & \\
\hline & TDN & DIN & DON & $\mathrm{NO}_{3}^{-}-\mathrm{N}$ & $\mathrm{NH}_{4}^{+}-\mathrm{N}$ & $\mathrm{SS}-\mathrm{NH}_{4}^{+}-\mathrm{N}$ & $\mathrm{TN}+\mathrm{SS}-\mathrm{NH}_{4}^{+}$ \\
\hline Concentration Arctic rivers $(\mu \mathrm{M})^{\mathrm{c}}$ & 14 & 2.7 & 12 & 2.0 & 0.7 & $\mathrm{n} / \mathrm{a}$ & n.d. \\
\hline Mean summer flux Arctic rivers $\left(\mathrm{Gg} \mathrm{a}^{-1}\right)^{\mathrm{d}}$ & 41 & 8.8 & 33 & 7.7 & $<0.5$ & n.d. & n.d. \\
\hline
\end{tabular}

$5.7 \mu \mathrm{mM}$ including SS-NH$H_{4}^{+}$) compared with those in snow and ice $(<1 \mu \mathrm{mM})$, reflecting enhancements in dissolved organic nitrogen, ammonium and nitrate (Fig. 3, Table 1). Similar findings have been reported at small valley glaciers (Hodson et al., 2008) and imply the acquisition of significant quantities of nitrogen within the glacier. A substantial proportion of this enhancement must occur in sedimentary environments at the ice sheet bed, as indicated by a significant association between TDN in moulin waters and bulk runoff but a positive intercept of $2.5 \mu \mathrm{mM}$ (Fig. 4). A range of possible sources exist for this additional nitrogen in runoff. Our wider contextual survey of the nitrogen content of basal and surface ice and meltwater and subglacial incubation experiments allows us to conjecture on these sources. For nitrate, enhancement is likely to occur in the subglacial environment, since nitrate concentrations in moulin waters and snow-ice are similar (Table 1). The basal regions of ice sheets are viable habitats for microbial life and previous work has demonstrated the activity of nitrifying bacteria, which transform ammonium to nitrate, at small Alpine valley glaciers (Boyd et al., 2011; Wynn et al., 2007) and subglacial Lake Whillans in Antarctica (Christner et al., 2014). In support of this, longterm incubation experiments using LG subglacial sediments (Fig. 5) show the release of up to $5 \mu \mathrm{M}$ nitrate under aerobic conditions in live sediments and an absence of this production in live controls (no sediment) and under anaerobic conditions. The simultaneous removal of ammonium ions is consistent with nitrification as the source of this nitrate, likely in more aerobic subglacial channel-marginal sedimentary environments.

The enhancement of DON concentrations in moulin waters relative to snow and ice and in runoff is also significant (independent $t$ test, $p=0.05$ ) and suggests the acquisition of DON in surface and basal ecosystems respectively. This is consistent with previous work that has suggested the presence of a significant nitrogen-rich component to dissolved organic matter exported from glacier ecosystems in runoff (Hood et al., 2009; Lawson et al., 2014b; Bhatia et al., 2013). 


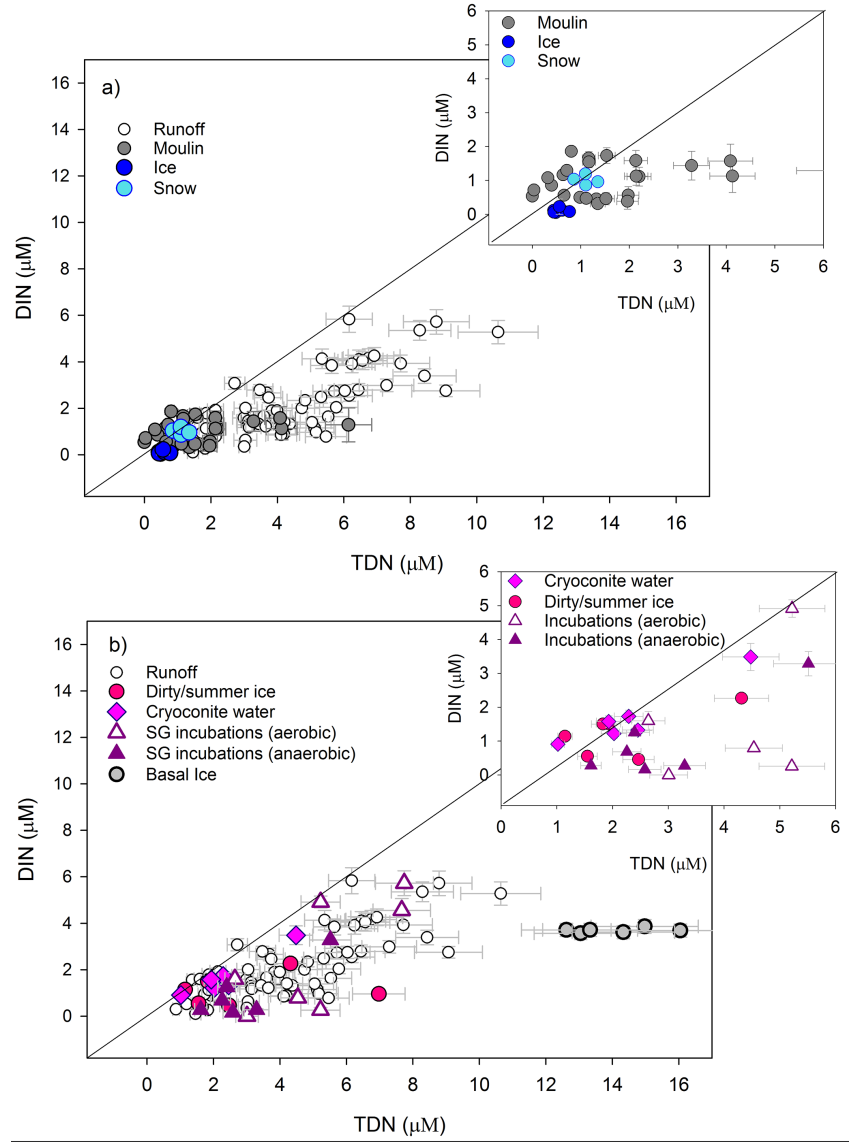

Figure 3. Associations between TDN and DIN in (a) runoff, moulin waters, snow and pre-melt ice, where data on snow and pre-melt ice are from Wolff (2013) and Telling et al. (2012) and (b) runoff and glacier surface ecosystems (cryoconite holes, summer ice including dispersed debris) and subglacial ecosystems (basal ice and meltwater sampled from anaerobic/aerobic long-term subglacial (SG) incubation experiments). A line indicates ratios of 1 for TDN/DIN where the TDN content of samples is entirely comprised of DIN. Samples that plot below this line have a dissolved organic nitrogen component. All samples have been blank-corrected, and error bars reflect the uncertainty of nutrient analyses given known precision and accuracy.

Likely surface sources are cryoconite holes and debris-rich ice, which display elevated DON concentrations relative to pre-melt ice and snow (Fig. 2, Table 1). These debris-laden environments support diverse microbial communities, which actively fix carbon dioxide from the atmosphere (Stibal et al., 2012). We assert that mineralization of organic matter in such environments generates the elevated DON concentrations in surface waters by microbial activity or by leaching from allochthonous organic matter in debris. The factor of 2 enhancement in DON concentrations in runoff relative to moulin waters reflects an even greater subglacial input of these nitrogen species. It is notable also that, while ammonium concentrations in bulk runoff are generally low

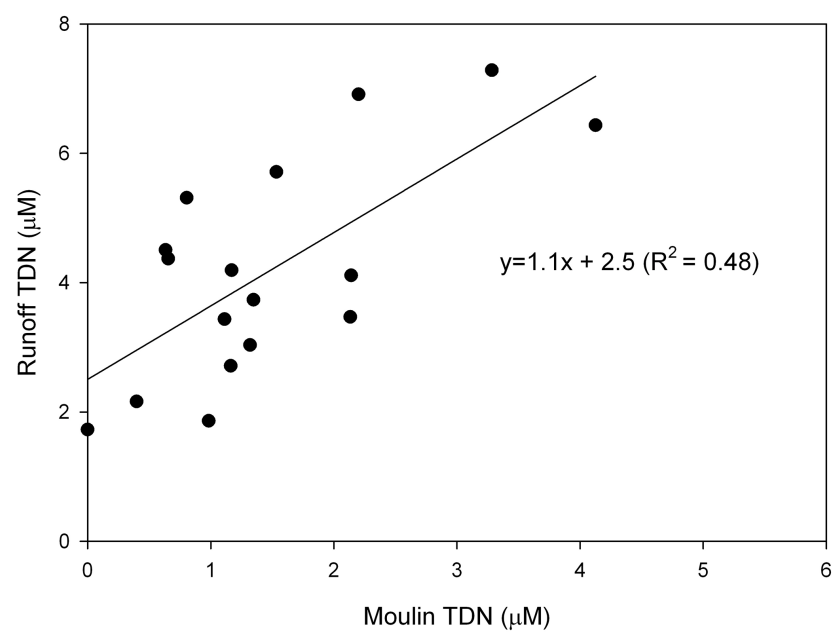

Figure 4. Association between the TDN concentrations measured simultaneously at the moulin and runoff monitoring sites (the correlation is significant at the $99 \%$ confidence level). Insets show the same data (excluding runoff samples) at low concentrations $(<6 \mu \mathrm{M})$.

( $<$ detection limit at $0.6 \mu \mathrm{M})$, both DON and ammonium concentrations in runoff are often elevated during subglacial outburst events, rising to up to concentrations of 3 and $6 \mu \mathrm{M}$ respectively (Figs. 2 and 6). These events are known to expel long-term stored meltwater and sediments from beneath the ice sheet in response to surface lakes drainage (Bartholomew et al., 2011). A subglacial source of these waters is clearly evident from elevated sulfate concentrations, which also rise during outburst events (Fig. 6). Sulfate ions are uniquely generated in inefficient distributed drainage pathways at the glacier bed, where comminution of the underlying bedrock releases highly reactive iron sulfide minerals to meltwater. These oxidize rapidly to give dissolved sulfate (Tranter et al., 1993). The elevated runoff DON and ammonium during such events implies a source in subglacial sedimentary ecosystems. Long-term incubation experiments presented in Fig. 5 strongly support a subglacial source for DON but do not show elevated concentrations of ammonium in live experiments. We propose that the subglacial acquisition of DON reflects in situ microbial activity, as reported beneath smaller valley glaciers (Hodson et al., 2005). The low dissolved organic carbon (DOC): DON ratio in runoff $($ mean $=9.5$, DOC data from Hawkings, 2015) is similar to other world glaciers (Hood and Scott, 2008) and is consistent with a microbial source for DON. It contrasts with the higher mean DOC : DON ratios for Arctic rivers $($ mean $=48)$, which include a greater terrestrial contribution (Lobbes et al., 2000). These findings support the notion that dissolved organic matter exported from the GrIS may be highly bioavailable to marine bacteria (Lawson et al., 2014a, b; Bhatia et al., 2010), as has been suggested for glacier systems elsewhere (Hood et al., 2009). 

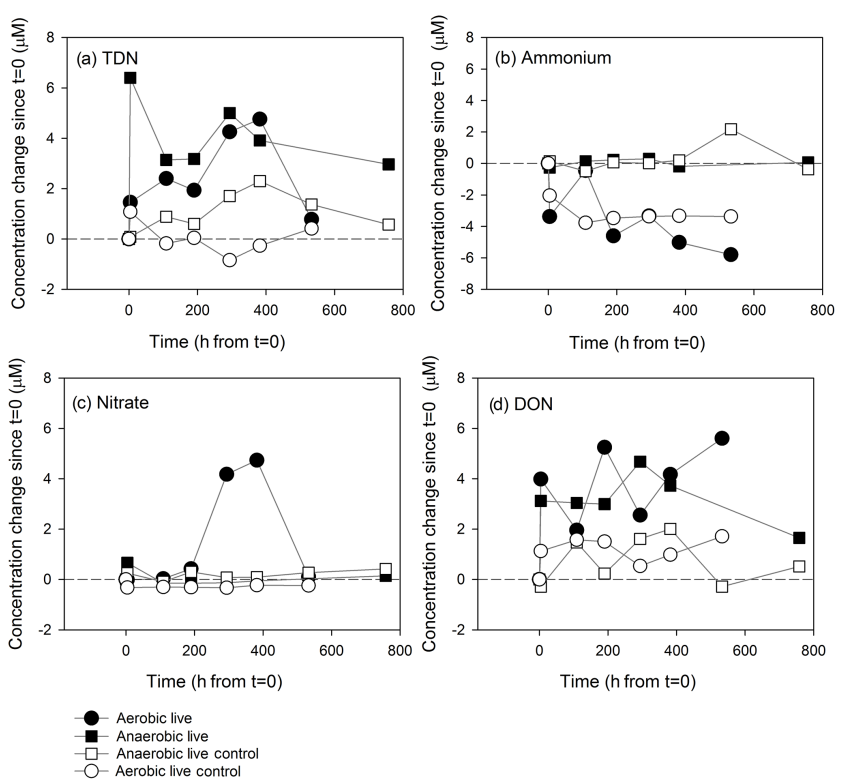

Figure 5. Time series of (a) TDN, (b) ammonium, (c) nitrate and (d) DON concentrations in anaerobic and aerobic live incubation experiments of subglacial sediments and sediment-free control experiments.

The subglacial source of the enhanced ammonium concentrations in long-term stored subglacial waters released during outburst events is less clear. Ammonium concentrations in basal ice and outburst waters were relatively high (mean =2-3 $\mu \mathrm{M}$; Table 1; Fig. 6), but our subglacial incubation experiments time series showed no significant enhancement of ammonium from initial concentrations over time (Fig. 5). Enhancement of ammonium concentrations in long-term stored subglacial meltwater has been documented previously in Antarctic subglacial Lake Whillans, inferred to reflect microbial mineralization (Christner et al., 2014). There are several potential reasons for the static ammonium concentrations during our laboratory experiments. It may reflect the difficulty of replicating microbial processes under laboratory conditions, together with elevated starting ammonium concentrations at $t=0$ in experiments (basal ice mean $\left.\mathrm{NH}_{4}^{+}=2.7 \mu \mathrm{M}\right)$. Second, it may indicate that the subglacial process that generates ammonium ions is not modelled well by laboratory experiments. For example, ammonium may be released to solution directly or indirectly by crushing of the underlying bedrock (Dixon et al., 2012), as occurs for other species such as hydrogen (Telling et al., 2015). Greenland gneiss contains very small concentrations of nitrogen ( $9 \mu \mathrm{g} \mathrm{N} \mathrm{g}^{-1}$; Holloway and Dahlgren, 2002), but glacial crushing and release of this nitrogen from bedrock as ammonium has the potential to generate concentrations an order of magnitude higher concentrations of ammonium than those observed in incubation experiments. Overall, data presented here suggest the operation of a suite of diverse
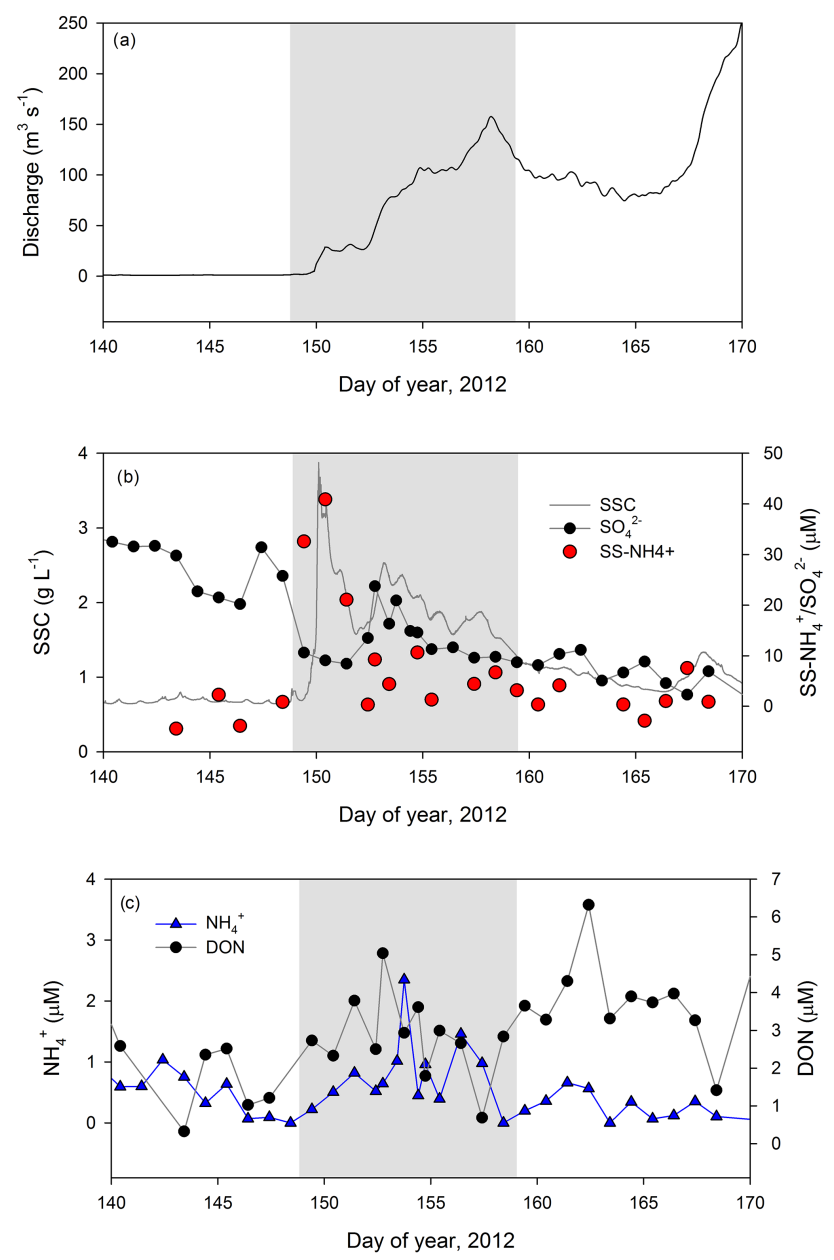

Figure 6. Times series of (a) bulk discharge, (b) concentrations of sediment-bound $\mathrm{NH}_{4}^{+}\left(\mathrm{P}-\mathrm{NH}_{4}^{+}\right)$and dissolved sulfate, and (c) concentrations of DON and dissolved $\mathrm{NH}_{4}^{+}$in runoff measured during the first (and main) subglacial outburst event during the 2012 season.

mechanisms that supply nitrogen species from snow and ice melt, enhancing them in supra- and subglacial ecosystems prior to meltwater being evacuated at the ice margin. This is consistent with recent work in Alpine regions that clearly demonstrated the potential for glacier-fed catchments to display enhanced nitrogen concentrations in runoff relative to snowmelt-fed systems (Saros et al., 2010).

\subsection{Fluxes of nitrogen from Leverett Glacier}

Total dissolved nitrogen (including $\mathrm{SS}-\mathrm{NH}_{4}^{+}$) fluxes from LG in summer are on average $142 \mathrm{ta}^{-1}$ (Table 2). The estimated TDN yields for the Leverett Glacier catchment arising from this flux are $236 \mathrm{~kg} \mathrm{~km}^{-2}\left(164 \mathrm{~kg} \mathrm{~m}^{-2} \mathrm{a}^{-1}\right.$ excluding $\mathrm{SS}_{-} \mathrm{NH}_{4}^{+}$), which is an order of magnitude higher than the typical annual TDN yields measured in large Arctic rivers $\left(36-81 \mathrm{~kg} \mathrm{~km}^{-2}\right.$; Holmes et al., 2012). This high 
yield largely arises from the high specific water yield at LG $\left(3.7 \times 10^{6} \mathrm{~m}^{3} \mathrm{~km}^{-2} \mathrm{a}^{-1}\right)$, in comparison to the water yield (July-October) of the largest Arctic rivers, which is 2 orders of magnitude lower $\left(9.3 \times 10^{4} \mathrm{~m}^{3} \mathrm{~km}^{-2} \mathrm{a}^{-1}\right.$, calculated from a water flux for the six largest Arctic rivers of $1011 \mathrm{~km}^{3} \mathrm{a}^{-1}$ from July to October and a gauged catchment area of $10.9 \times 10^{6} \mathrm{~km}^{2}$; Holmes et al., 2012). This implies that there is a much higher continuous flux of dissolved nitrogen species per unit area from the ice sheet in summer than from High Arctic river catchments, reflecting the acquisition of dissolved $\mathrm{N}$ species from both melting snow and ice on the surface and sedimentary environments at the ice sheet bed.

\subsection{Fluxes of nitrogen from the Greenland Ice Sheet}

The estimated summer mid-range TN flux (including SS$\mathrm{NH}_{4}^{+}$) from the GrIS is $\sim 27 \mathrm{Gg}(2000-2011)$ and $43 \mathrm{Gg}$ (2012; Table 3) using discharge weighted mean concentrations, with potential flux ranges of 7-86 and 11-137 for 2000-2010 and 2012 respectively. The mean values are of a similar order of magnitude to a large Arctic river (the average TDN flux for the Lena, Yenisei and Ob rivers, JulyOctober is $41 \mathrm{Gg}$; Holmes et al., 2012). The glacial nitrogen fluxes largely supply different ocean basins to the Arctic rivers (Bamber et al., 2012; Holmes et al., 2012). We contend that ice-sheet-derived nitrogen fluxes are likely to rise with enhanced melting in a warmer climate and could, therefore, stimulate increased primary production in downstream coastal ecosystems. Evidence from a single melt year suggests that within-season fluxes of nitrogen species rise exponentially with increasing glacial water fluxes (Fig. 2). The degree of future nitrogen flux increase in warm melt years, however, is difficult to predict. The atmospheric nitrogen flux (largely as DIN) is likely to scale with increasing melt volumes as has been suggested elsewhere (Hawkings et al., 2015). However, the magnitude of increase will depend upon the availability of glacial ice and snow from post-industrial times, since these display elevated atmospheric DIN compared with pre-industrial ice (Olivier et al., 2006). DON and non-atmospheric ammonium fluxes might also be expected to increase as the zone of melting expands, and there is more extensive contact of meltwater with organic matter in surface and subglacial ecosystems.

The impact of present and future nitrogen fluxes upon fjord and coastal marine ecosystems around Greenland is unknown and requires further study. The input of nutrients associated with Greenland icebergs and runoff may sustain elevated primary productivity beyond the spring phytoplankton bloom and offers one possible explanation for the reported mid-summer phytoplankton bloom in western Greenland (Frajka-Williams and Rhines, 2010; Nielsen and Hansen, 1999). Nitrogen limitation is common in fjord and coastal waters in summer, and hence any increase in DIN supply has the potential to enhance primary productivity.

\section{Conclusions}

In summary, our findings at Leverett Glacier suggest that large glacial outlet glaciers draining the Greenland Ice Sheet provide a continuous source of dissolved nitrogen in runoff through the summer months, a proportion of which is likely to originate from microbial ecosystems on and beneath the ice. The degree to which these nitrogen fluxes are modified by proglacial processes is unknown, as are the potential impacts upon fjord and coastal marine biological productivity. However, phytoplankton in coastal Greenlandic waters often become limited by nitrogen availability by mid-summer, when the glacial nitrogen flux to coastal waters is highest. TDN yields from Leverett Glacier are an order of magnitude higher than those reported for Arctic rivers, a reflection of the high surface melt rates (and hence water fluxes) and continuous nitrogen supply from several sources within the ice sheet. Estimated fluxes of nitrogen from the ice sheet are similar in magnitude to those of a large Arctic river. Our findings suggest that a melting GrIS may be an important source of nitrogen to downstream coastal ecosystems and that these nitrogen fluxes are likely to increase in a warming climate.

\section{The Supplement related to this article is available online at doi:10.5194/bg-13-6339-2016-supplement.}

Acknowledgements. This research is part of the UK Natural Environment Research Council, NERC-funded DELVE project (NERC grant NE/I008845/1). It was also funded by NERC grants NE/E004016/1 to J. L. Wadham, NE/F0213991 to P. W. Nienow and a NERC CASE studentship to E. C. Lawson (NERC DTG/GEOG SN1316.6525) co-sponsored by Dionex Corporation (part of Thermo Fisher Scientific) and a NERC PhD studentship to J. Hawkings. A. Tedstone was funded by a NERC studentship and MOSS scholarship. P. W. Nienow was supported by grants from the Carnegie Trust for University of Scotland and The University of Edinburgh Development Trust. Additional support was provided by the Leverhulme Trust, via a Leverhulme research fellowship to J. L. Wadham. We thank all of those who assisted with fieldwork at LG and to Fanny Monteiro, who provided comments on an earlier draft. The work was also supported by the Cabot Institute at the University of Bristol.

Edited by: B. A. Pellerin

Reviewed by: two anonymous referees

\section{References}

Arendt, K. E., Nielsen, T. G., Rysgaard, S., and Tonnesson, K.: Differences in plankton community structure along the Godthabsfjord, from the Greenland Ice Sheet to offshore waters, Mar. Ecol.-Prog. Ser., 401, 49-62, doi:10.3354/Meps08368, 2010. 
Bamber, J., van den Broeke, M., Ettema, J., Lenaerts, J., and Rignot, E.: Recent large increases in freshwater fluxes from Greenland into the North Atlantic, Geophys. Res. Lett., 39, L19501, doi:10.1029/2012g1052552, 2012.

Bartholomew, I., Nienow, P., Sole, A., Mair, D., Cowton, T., Palmer, S., and Wadham, J.: Supraglacial forcing of subglacial drainage in the ablation zone of the Greenland ice sheet, Geophys. Res. Lett., 38, L08502, doi:10.1029/2011gl047063, 2011.

Bhatia, M. P., Das, S. B., Longnecker, K., Charette, M. A., and Kujawinski, E. B.: Molecular characterization of dissolved organic matter associated with the Greenland ice sheet, Geochim. Cosmochim. Ac., 74, 3768-3784, doi:10.1016/j.gca.2010.03.035, 2010.

Bhatia, M. P., Das, S. B., Xu, L., Charette, M. A., Wadham, J. L., and Kujawinski, E. B.: Organic carbon export from the Greenland ice sheet, Geochim. Cosmochim. Ac., 109, 329-344, doi:10.1016/j.gca.2013.02.006, 2013.

Bower, C. E. and Holm-Hansen, T.: A Salicylate-Hypochlorite Method for Determining Ammonia in Seawater, Can. J. Fish. Aquat. Sci., 37, 794-798, doi:10.1139/f80-106, 1980.

Boyd, E. S., Lange, R. K., Mitchell, A. C., Havig, J. R., Hamilton, T. L., Lafreniere, M. J., Shock, E. L., Peters, J. W., and Skidmore, M.: Diversity, Abundance, and Potential Activity of Nitrifying and Nitrate-Reducing Microbial Assemblages in a Subglacial Ecosystem, Appl. Environ. Microb., 77, 4778-4787, doi:10.1128/Aem.00376-11, 2011

Budeus, G. and Schneider, W.: On the Hydrography of the Northeast Water Polynya, J. Geophys. Res.-Oceans, 100, 4287-4299, doi:10.1029/94jc02024, 1995.

Chandler, D. M., Wadham, J. L., Lis, G. P., Cowton, T., Sole, A., Bartholomew, I., Telling, J., Nienow, P., Bagshaw, E. B., Mair, D., Vinen, S., and Hubbard, A.: Evolution of the subglacial drainage system beneath the Greenland Ice Sheet revealed by tracers, Nat. Geosci., 6, 195-198, doi:10.1038/Ngeo1737, 2013.

Christner, B. C., Priscu, J. C., Achberger, A. M., Barbante, C., Carter, S. P., Christianson, K., Michaud, A. B., Mikucki, J. A., Mitchell, A. C., Skidmore, M. L., Vick-Majors, T. J., and the WISSARD science team: A microbial ecosystem beneath the West Antarctic ice sheet, Nature, 512, 310-313, doi:10.1038/nature13667, 2014.

Cowton, T., Nienow, P., Bartholomew, I., Sole, A., and Mair, D.: Rapid erosion beneath the Greenland ice sheet, Geology, 40, 343-346, doi:10.1130/g32687.1, 2012.

Cowton, T., Nienow, P., Sole, A., Wadham, J., Lis, G., Bartholomew, I., Mair, D., and Chandler, D.: Evolution of drainage system morphology at a land-terminating Greenlandic outlet glacier, J. Geophys. Res.-Earth, 118, 29-41, doi:10.1029/2012jf002540, 2013.

Daly, K. L., Wallace, D. W. R., Smith, W. O., Skoog, A., Lara, R., Gosselin, M., Falck, E., and Yager, P. L.: Non-Redfield carbon and nitrogen cycling in the Arctic: Effects of ecosystem structure and dynamics, J. Geophys. Res.-Oceans, 104, 3185-3199, doi:10.1029/1998jc900071, 1999.

Dixon, J. C., Campbell, S. W., and Durham, B.: Geologic nitrogen and climate change in the geochemical budget of Kärkevagge, Swedish Lapland, Geomorphology, 167-168, 70-76, 2012.

Frajka-Williams, E. and Rhines, P. B.: Physical controls and interannual variability of the Labrador Sea spring phytoplankton bloom in distinct regions, Deep-Sea Res. Pt. I, 57, 541-552, doi:10.1016/j.dsr.2010.01.003, 2010.

Hamilton, L., Lyster, P., and Otterstad, O.: Social Change, Ecology and Climate in 20th-Century Greenland, Climatic Change, 47, 193-211, doi:10.1023/a:1005607426021, 2000.

Hawkings, J., Wadham, J. L., Tranter, M., Raiswell, R., Benning, L. G., Statham, P. J., Tedstone, A., and Nienow, P.: Ice sheets as a significant source of highly reactive nanoparticulate iron to the oceans, Nat. Commun., 5, 3929, doi:10.1038/ncomms4929, 2014.

Hawkings, J.: An investigation into the production and export of nutrients from glaciers $\mathrm{PhD}$, School of Geographical Sciences, University of Bristol, Bristol, 241 pp., 2015.

Hawkings, J., Wadham, J. L., Tranter, M., Telling, J., Bagshaw, E. A., Beaton, A., Simmons, S. L., Tedstone, A., and Nienow, P. W.: The Greenland Ice Sheet as a hot spot of phosphorus weathering and export in the Arctic, Global Biogeochem. Cy., 30, 191-210, 2016.

Hawkings, J. R., Wadham, J. L., Tranter, M., Lawson, E., Sole, A., Cowton, T., Tedstone, A. J., Bartholomew, I., Nienow, P., Chandler, D., and Telling, J.: The effect of warming climate on nutrient and solute export from the Greenland Ice Sheet, Geochemical Perspectives Letters, 1, 94-104, doi:10.7185/geochemlet.1510, 2015.

Hodson, A., Anesio, A. M., Tranter, M., Fountain, A., Osborn, M., Priscu, J., Laybourn-Parry, J., and Sattler, B.: Glacial ecosystems, Ecol. Monogr., 78, 41-67, 2008.

Hodson, A. J., Mumford, P. N., Kohler, J., and Wynn, P. M.: The High Arctic glacial ecosystem: new insights from nutrient budgets, Biogeochemistry, 72, 233-256, doi:10.1007/s10533-0040362-0, 2005.

Holloway, J. M. and Dahlgren, R. A.: Nitrogen in rock: Occurrences and biogeochemical implications, Global Biogeochem. Cy., 16, 65-1-65-17, doi:10.1029/2002GB001862, 2002.

Holmes, R. M., McClelland, J. W., Peterson, B. J., Tank, S. E., Bulygina, E., Eglinton, T. I., Gordeev, V. V., Gurtovaya, T. Y., Raymond, P. A., Repeta, D. J., Staples, R., Striegl, R. G., Zhulidov, A. V., and Zimov, S. A.: Seasonal and Annual Fluxes of Nutrients and Organic Matter from Large Rivers to the Arctic Ocean and Surrounding Seas, Estuar. Coast., 35, 369-382, doi:10.1007/s12237-011-9386-6, 2012.

Hood, E. and Scott, D.: Riverine organic matter and nutrients in southeast Alaska affected by glacial coverage, Nat. Geosci., 1, 583-587, doi:10.1038/Ngeo280, 2008.

Hood, E., Fellman, J., Spencer, R. G. M., Hernes, P. J., Edwards, R., D'Amore, D., and Scott, D.: Glaciers as a source of ancient and labile organic matter to the marine environment, Nature, 462, 1044-1100, doi:10.1038/Nature08580, 2009.

Hopwood, M. J., Connelly, D. P., Arendt, K. E., Juul-Pedersen, T., Stinchcombe, M., Meire, L., Esposito, M., and Krishna, R.: Seasonal changes in Fe along a glaciated Greenlandic fjord, Front. Earth Sci., 4, 15, doi:10.3389/feart.2016.00015, 2016.

IPCC: Climate Change 2007: The Physical Science Basis, in: Contribution of Working Group I to the Fourth Assessment Report of the Intergovernmental Panel on Climate Change, edited by: Solomon, S., Qin, D., Manning, M., Chen, Z., Marquis, M., Averyt, K. B., Tignor, M., and Miller, H. L., Cambridge University Press, Cambridge, United Kingdom and New York, NY, USA, 2007. 
Jensen, H. M., Pedersen, L., Burmeister, A., and Hansen, B. W.: Pelagic primary production during summer along 65 to 72 degrees N off West Greenland, Polar Biol., 21, 269-278, doi:10.1007/s003000050362, 1999.

Kalsbeek, F.: The evolution of the Precambrian shield of Greenland, Geol. Runsch., 71, 38-60, 1982.

Kalsbeek, F. and Taylor, P. N.: Pb-isotopic studies of proterozoic igneous rocks, west Greenland, with implications on the evolution of the Greenland shield, in: The deep Proterozoic crust in the North Atlantic Provinces, NATO ASI Series, Series C, Mathematical and Physical Sciences, D. Reidal Publishing Company, 1984.

Lawson, E. C., Wadham, J. L., Tranter, M., Stibal, M., Lis, G. P., Butler, C. E. H., Laybourn-Parry, J., Nienow, P., Chandler, D., and Dewsbury, P.: Greenland Ice Sheet exports labile organic carbon to the Arctic oceans, Biogeosciences, 11, 4015-4028, doi:10.5194/bg-11-4015-2014, 2014a.

Lawson, E. C., Bhatia, M. P., Wadham, J. L., and Kujawinski, E. B.: Continuous Summer Export of Nitrogen-Rich Organic Matter from the Greenland Ice Sheet Inferred by Ultrahigh Resolution Mass Spectrometry, Environ. Sci. Technol., 48, 14248-14257, doi:10.1021/es501732h, 2014b.

Le, P. T. T. and Boyd, C. E.: Comparison of Phenate and Salicylate Methods for Determination of Total Ammonia Nitrogen in Freshwater and Saline Water, J. World Aquacult. Soc., 43, 885889, doi:10.1111/j.1749-7345.2012.00616.x, 2012.

Lobbes, J. M., Fitznar, H. P., and Kattner, G.: Biogeochemical characteristics of dissolved and particulate organic matter in Russian rivers entering the Arctic Ocean, Geochim. Cosmochim. Ac., 64, 2973-2983, doi:10.1016/S0016-7037(00)00409-9, 2000.

Maynard, D. G., Kalra, Y. P., and Crumgaugh, J. A.: Nitrate and exchangeable ammonium nitrogen, in: Soil Sampling and Methods of Analysis, edited by: Carter, M. R. and Gregorich, E. G., CRC Press, Boca Raton, Fla, 2007

Moore, J. K., Doney, S. C., Glover, D. M., and Fung, I. Y.: Iron cycling and nutrient-limitation patterns in surface waters of the World Ocean, Deep-Sea Res. Pt. II, 49, 463-507, 2002.

Nielsen, M. H., Erbs-Hansen, D. R., and Knudsen, K. L.: Water masses in Kangerlussuaq, a large fjord in West Greenland: the processes of formation and the associated foraminiferal fauna, Polar Res., 29, 159-175, doi:10.1111/j.17518369.2010.00147.x, 2010.

Nielsen, T. G. and Hansen, B. W.: Plankton community structure and carbon cycling on the western coast of Greenland during the stratified summer situation. I. Hydrography, phytoplankton and bacterioplankton, Aquat. Microb. Ecol., 16, 205-216, doi:10.3354/Ame016205, 1999.

Olivier, S., Blaser, C., Brutsch, S., Frolova, N., Gaggeler, H. W., Henderson, K. A., Palmer, A. S., Papina, T., and Schwikowski, M.: Temporal variations of mineral dust, biogenic tracers, and anthropogenic species during the past two centuries from Belukha ice core, Siberian Altai, J. Geophys. Res.-Atmos., 111, D05309, doi:10.1029/2005jd005830, 2006.

Podgorny, I. A. and Grenfell, T. C.: Absorption of solar energy in a cryoconite hole, Geophys. Res. Lett., 23, 2465-2468, doi:10.1029/96GL02229, 1996.

Poulsen, L. K. and Reuss, N.: The plankton community on Sukkertop and Fylla Banks off West Greenland during a spring bloom and post-bloom period: Hydrography, phytoplankton and protozooplankton, Ophelia, 56, 69-85, 2002.

Rysgaard, S., Nielsen, T. G., and Hansen, B. W.: Seasonal variation in nutrients, pelagic primary production and grazing in a high-Arctic coastal marine ecosystem, Young Sound, Northeast Greenland, Mar. Ecol.-Prog. Ser., 179, 13-25, doi:10.3354/Meps179013, 1999.

Sabine, C. L., Feely, R. A., Gruber, N., Key, R. M., Lee, K., Bullister, J. L., Wanninkhof, R., Wong, C. S., Wallace, D. W. R., Tilbrook, B., Millero, F. J., Peng, T. H., Kozyr, A., Ono, T., and Rios, A. F.: The oceanic sink for anthropogenic $\mathrm{CO}(2)$, Science, 305, 367-371, 2004.

Saros, J. E., Rose, K. C., Clow, D. W., Stephens, V. C., Nurse, A. B., Arnett, H. A., Stone, J. R., Williamson, C. E., and Wolfe, A. P.: Melting Alpine Glaciers Enrich High-Elevation Lakes with Reactive Nitrogen, Environ. Sci. Technol., 44, 4891-4896, doi:10.1021/es100147j, 2010.

Simpson, M. J. R., Milne, G. A., Huybrechts, P., and Long, A. J.: Calibrating a glaciological model of the Greenland ice sheet from the Last Glacial Maximum to present-day using field observations of relative sea level and ice extent, Quaternary Sci. Rev., 28, 1631-1657, 2009.

Smith Jr., K. L., Sherman, A. D., Shaw, T. J., and Sprintall, J.: Icebergs as Unique Lagrangian Ecosystems in Polar Seas, Annu. Rev. Mar. Sci., 5, 269-287, doi:10.1146/annurev-marine121211-172317, 2013.

Smith, S. L., Smith, W. O., Codispoti, L. A., and Wilson, D. L.: Biological Observations in the Marginal Ice-Zone of the East Greenland Sea, J. Mar. Res., 43, 693-717, 1985.

Stibal, M., Telling, J., Cook, J., Mak, K. M., Hodson, A., and Anesio, A. M.: Environmental Controls on Microbial Abundance and Activity on the Greenland Ice Sheet: A Multivariate Analysis Approach, Microb. Ecol., 63, 74-84, doi:10.1007/s00248-0119935-3, 2012.

Syvitski, J. P. M., Stein, A. B., Andrews, J. T., and Milliman, J. D.: Icebergs and the sea floor of the East Greenland (Kangerlussuaq) continental margin, Arct. Antarct. Alp. Res., 33, 52-61, doi:10.2307/1552277, 2001.

Tedesco, M., Fettweis, X., Mote, T., Wahr, J., Alexander, P., Box, J. E., and Wouters, B.: Evidence and analysis of 2012 Greenland records from spaceborne observations, a regional climate model and reanalysis data, The Cryosphere, 7, 615-630, doi:10.5194/tc7-615-2013, 2013.

Tedstone, A. J., Nienow, P. W., Sole, A. J., Mair, D. W. F., Cowton, T. R., Bartholomew, I. D., and King, M. A. Greenland ice sheet motion insensitive to exceptional meltwater forcing, P. Natl. Acad. Sci. USA, 110, 19719-19724, doi:10.1073/pnas.1315843110, 2013.

Telling, J., Anesio, A. M., Tranter, M., Irvine-Fynn, T., Hodson, A., Butler, C., and Wadham, J.: Nitrogen fixation on Arctic glaciers, Svalbard, J. Geophys. Res.-Biogeo., 116, G03039, doi:10.1029/2010jg001632, 2011.

Telling, J., Stibal, M., Anesio, A. M., Tranter, M., Nias, I., Cook, J., Bellas, C., Lis, G., Wadham, J. L., Sole, A., Nienow, P., and Hodson, A.: Microbial nitrogen cycling on the Greenland Ice Sheet, Biogeosciences, 9, 2431-2442, doi:10.5194/bg-9-24312012, 2012.

Telling, J., Boyd, E. S., Bone, N., Jones, E. L., Tranter, M., MacFarlane, J. W., Martin, P. G., Wadham, J. L., Lamarche-Gagnon, 
G., Skidmore, M. L., Hamilton, T. L., Hill, E., Jackson, M., and Hodgson, D. A.: Rock comminution as a source of hydrogen for subglacial ecosystems, Nat. Geosci., 8, 851-855, doi:10.1038/ngeo2533, 2015.

Tranter, M., Brown, G. H., and Sharp, M. J.: The Use of Sulfate as a Tracer for the Delayed Flow Component of Alpine Glacial Runoff, Tracers in Hydrology, 350, 89-98, 1993.

Vancoppenolle, M., Bopp, L., Madec, G., Dunne, J., Ilyina, T., Halloran, P. R., and Steiner, N.: Future Arctic Ocean primary productivity from CMIP5 simulations: Uncertain outcome, but consistent mechanisms, Global Biogeochem. Cy., 1-15, doi:10.1002/gbc.20055, 2013.

Vernon, C. L., Bamber, J. L., Box, J. E., van den Broeke, M. R., Fettweis, X., Hanna, E., and Huybrechts, P.: Surface mass balance model intercomparison for the Greenland ice sheet, The Cryosphere, 7, 599-614, doi:10.5194/tc-7-599-2013, 2013.
Wadham, J. L., Tranter, M., Skidmore, M., Hodson, A. J., Priscu, J., Lyons, W. B., Sharp, M., Wynn, P., and Jackson, M.: Biogeochemical weathering under ice: Size matters, Global Biogeochem. Cy., 24, GB3025, 10.1029/2009gb003688, 2010.

Wolff, E. W.: Ice sheets and nitrogen, Philos. T. R. Soc. B, 368, 20130127, doi:10.1098/Rstb.2013.0127, 2013.

Wynn, P. M., Hodson, A. J., Heaton, T. H. E., and Chenery, S. R.: Nitrate production beneath a High Arctic Glacier, Svalbard, Chem. Geol., 244, 88-102, doi:10.1016/j.chemgeo.2007.06.008, 2007. 